\title{
Influences on Mercury Bioaccumulation Factors for the Savannah River
}

by

M. H. Paller

Westinghouse Savannah River Company

Savannah River Site

Aiken, South Carolina 29808

J. A. Bowers

DOE Contract No. DE-AC09-96SR18500

This paper was prepared in connection with work done under the above contract number with the U.S. Department of Energy. By acceptance of this paper, the publisher and/or recipient acknowledges the U. S.

Government's right to retain a nonexclusive, royalty-free license in and to any copyright covering this paper, along with the right to reproduce and to authorize others to reproduce all or part of the copyrighted paper. 
This document was prepared in conjunction with work accomplished under Contract No. DE-AC09-96SR18500 with the U. S. Department of Energy.

\section{DISCLAIMER}

This report was prepared as an account of work sponsored by an agency of the United States Government. Neither the United States Government nor any agency thereof, nor any of their employees, makes any warranty, express or implied, or assumes any legal liability or responsibility for the accuracy, completeness, or usefulness of any information, apparatus, product or process disclosed, or represents that its use would not infringe privately owned rights. Reference herein to any specific commercial product, process or service by trade name, trademark, manufacturer, or otherwise does not necessarily constitute or imply its endorsement, recommendation, or favoring by the United States Government or any agency thereof. The views and opinions of authors expressed herein do not necessarily state or reflect those of the United States Government or any agency thereof.

This report has been reproduced directly from the best available copy.

Available for sale to the public, in paper, from: U.S. Department of Commerce, National Technical Information Service, 5285 Port Royal Road, Springfield, VA 22161, phone: (800) 553-6847, fax: (703) 605-6900

email: orders@ntis.fedworld.gov

online ordering: http://www.ntis.gov/help/index.asp

Available electronically at http://www.osti.gov/bridge

Available for a processing fee to U.S. Department of Energy and its contractors, in paper, from: U.S. Department of Energy, Office of Scientific and Technical Information, P.O. Box 62, Oak Ridge, TN 37831-0062,

phone: (865)576-8401,

fax: (865)576-5728

email: $\underline{\text { reports@ adonis.osti.gov }}$ 
WSRC-MS-2002-01015

\title{
Influences on Mercury Bioaccumulation Factors for the Savannah River
}

\author{
Michael H. Paller and James A. Bowers \\ Westinghouse Savannah River Company \\ Aiken, SC 29808 USA
}

\begin{abstract}
Mercury TMDLs (Total Maximum Daily Loads) are a regulatory instrument designed to reduce the amount of mercury entering a water body and ultimately to control the bioaccumulation of mercury in fish. TMDLs are based on a BAF (bioaccumulation factor), which is the ratio of methyl mercury in fish to dissolved methyl mercury in water. Analysis of fish tissue and aqueous methyl mercury samples collected at a number of locations and over several seasons in a $118 \mathrm{~km}$ reach of the Savannah River demonstrated that species specific BAFs varied by factors of three to eight. Factors contributing to BAF variability were location, habitat and season related differences in fish muscle tissue mercury levels and seasonal differences in dissolved methyl mercury levels. Overall (all locations, habitats, and seasons) average BAFs were $3.7 \times 10^{6}$ for largemouth bass, $1.4 \times 10^{6}$ for sunfishes, and $2.5 \times 10^{6}$ for white catfish. Inaccurate and imprecise BAFs can result in unnecessary economic impact or insufficient protection of human health. Determination of representative and precise BAFs for mercury in fish from large rivers necessitates collecting large and approximately equal numbers of fish and aqueous methyl mercury samples over a seasonal cycle from the entire area and all habitats to be represented by the TMDL.
\end{abstract}


WSRC-MS-2002-01015

\section{Introduction}

Mercury is a neurotoxic contaminant that is widespread in aquatic ecosystems. Mercury accumulates in fish primarily as methylmercury (Bloom 1992), which is produced in aquatic environments by the action of microorganisms on inorganic mercury (Gilmour et al. 1992). Mercury enters fish through their diet and concentrates in muscle tissue to levels far higher than found in the ambient water (Clarkson 1990, Downs et al. 1998). Because of food chain bioaccumulation, higher concentrations usually occur in predatory fishes than in fishes that feed at lower trophic levels (Cabana et al. 1994, USEPA 1997). Consumption of contaminated fish (and other aquatic organisms) is the major route by which mercury enters human and wildlife food chains (Eisler 1987, Clarkson 1990).

Regulatory agencies in the United States are in the process of developing TMDLs (total maximum daily loads) for mercury in various water bodies in an effort to reduce mercury loading from the surrounding watershed and protect human and ecological health (EPA 1994, EPA 2000). TMDL computations involve the determination of a target concentration for mercury in water that is based on a bioaccumulation factor (BAF, EPA 1997). The BAF is the ratio of the concentration of mercury in fish flesh to the concentration of mercury (usually dissolved methyl mercury) in the water (EPA 1997). The BAF has a critical effect on the results of TMDL computations and subsequently on the efficacy and economic impact of regulations stemming from the TMDL.

The USEPA has developed default BAFs for mercury that can be used when site specific data is lacking (EPA 1997). However, mercury BAFs are influenced by many factors including water chemistry, food chain lengths, temperature, fish diet, and others (Cope et al. 1990, Downs et al. 1998, Bowles et al. 2001). EPA (1977) default BAFs are derived largely from fish and water chemistry data collected from northern lakes that 
WSRC-MS-2002-01015

may differ chemically and ecologically from running waters and from waters located in other geographic regions. The EPA (1977) recognizes the limitations of default BAFs and recommends that site specific BAFs be used whenever possible.

Collection of representative data for computation of site specific BAFs is complicated by temporal and spatial variations in aqueous and fish tissue mercury levels. Aqueous mercury levels can exhibit substantial temporal variation associated with changes in oxygen concentration, precipitation, temperature, water level, and wetland runoff (Sellers et al. 2001, Hurley et al. 1998, Regnell et al. 1997). Mercury levels generally vary less in fish muscle tissue (Downs et al. 1998, Foster et al. 2000), where biological half lives can be as long as one to three years (McKim et al. 1976, Burrows and Krenkel 1973), However, substantial seasonal variation in fish muscle tissue mercury may result from variations in mercury uptake (Park and Curtis 1997). In addition, localized aggregations of fish from the same water body may exhibit significant spatial variations in mercury concentration as a likely result of differences in mercury bioavailability among foraging areas (Munn and Short 1997). The influence of these sources of variation on the representativeness and precision of site specific BAFs has not been thoroughly investigated. In this study, we collected aqueous and fish tissue mercury samples during several seasons and at a number of locations in the middle Savannah River permitting us to determine the magnitude of seasonal and spatial variation in mercury concentrations in both media. The objective was to assess the effects of this variability on mercury BAFs for Savannah River fish.

\section{Materials and Methods}

\section{$\underline{\text { Study area }}$}

The Savannah River is an important lotic ecosystem that forms the border between South Carolina and Georgia in the southeastern United States. The approximately $118 \mathrm{~km}$ reach under study was located in the upper coastal plain. It 
WSRC-MS-2002-01015

extended from below the Augusta Lock and Dam (RKM [river km] 302) to the Highway 301 bridge (RKM 192) and for part of its length was adjacent to the Savannah River Site, a US Department of Energy facility (Figure 1). Dissolved oxygen concentrations within this region averaged seven to eight $\mathrm{mg} / \mathrm{l}, \mathrm{pHs}$ were slightly acidic (around 6.0), and conductivities averaged near 70 (Paller et al. 1986). The study area included a number of "cut-off bends" or artificial oxbow lakes (hereafter referred to as "cuts") formed where loops of the river channel were by-passed by the Army Corps of Engineers during the 1960s to improve navigation efficiency. Although most cuts were still connected to the main river channel, the flow through them was reduced and dissolved oxygen concentrations were lower (nearing zero in a few backwater areas during warm weather, Paller et al. 1986). We observed that cuts were heavily fished by anglers, suggesting the importance of including them in a BAF study ultimately concerned with human exposure to mercury. There were no known industrial processes contributing mercury to the study area during the course of this study.

Field and laboratory methods

Fish and water samples were collected from three locations in the Savannah River: "upper river" (approximately RKM 300 - RKM 290), "middle river" (approximately RKM 223 - RKM 213), and "lower river" (approximately RKM 190 - RKM 182) (Figure 1). Each sampling location included two habitats, the main river channel and the backwaters found in cuts connected to the main channel. Two cuts were sampled in each location. Samples were collected during three time periods referred to as fall 2000, spring 2001, and late summer 2001. Fall 2000 included fish samples collected from $9 / 19 / 00$ through $11 / 15 / 00$ and water samples collected on $11 / 6 / 00$ and $11 / 7 / 00$. Spring 2001 included fish samples collected from 2/27/01 through 5/15/01 and water samples collected on 4/26/01. Late summer 2001 included fish samples collected from 8/20/01 through 10/8/01 and water samples collected on 9/10/01 and 9/11/01. 
WSRC-MS-2002-01015

Each habitat was electrofished to collect representatives from three taxonomic groups: largemouth bass Micropterus salmoides, white catfishes Ameiurus catus, and sunfishes (Lepomis spp). Largemouth bass in the size ranges collected in this study are largely piscivorous, while the other two taxa feed primarily on invertebrates. Sunfishes included redbreast sunfish Lepomis auritus, redear sunfish Lepomis microlophus, and bluegill Lepomis macrochirus. The pooling of sunfishes was necessary because of the limited availability of individual species. Extensive areas were sampled in an effort to collect at least five individuals from each taxonomic group in each habitat and location during each sample period. However, this goal was not always met (sample sizes for individual statistical tests are given in the results).

Fish were transferred to polyethylene zip-lock bags immediately following collection, placed on ice and brought to a laboratory where they were individually measured (total length to nearest $\mathrm{mm}$ ) and weighed (nearest $\mathrm{g}$ ). A muscle tissue sample weighing approximately $10 \mathrm{~g}$ was removed from the lateral posterior portion of each fish and frozen. In some cases, stomach contents were qualitatively evaluated to determine what the fish had been eating. Fish tissue samples were individually analyzed at the Savannah River Site Environmental Monitoring Laboratory for total mercury (ug/kg wet weight) using EPA method 245.6 (cold vapor atomic absorption spectrometry following tissue homogenization and digestion, EPA 1991). Differences between replicate samples averaged $9 \%$ and all results were above the detection limit.

Two filtered water samples for dissolved methyl mercury analysis were collected from each habitat (river and cut) in each location (upper, middle, and lower river) during each sample period. The two water samples from the river were collected near the beginning and the end of each sampling location and the two water samples from the cuts were collected from different cuts. Each sample was taken near the middle of the 
WSRC-MS-2002-01015

river or cut approximately $25 \mathrm{~cm}$ beneath the surface. A peristaltic pump and clean plastic tubing conveyed water from the river through a 0.45 micron glass-fiber filter into a pre-cleaned and marked teflon bottle (filter and bottle supplied by Frontier Geosciences). New filters were used for each sample, and the collecting tube was thoroughly flushed with ambient water before collecting each sample. Sampling was performed with clean sample handling techniques to prevent contamination (Bloom 1995, USEPA 2001). Samples were placed on ice and shipped the day of collection to a laboratory that specialized in ultra-low level methylmercury analyses (Frontier Geosciences) using gas chromatography and cold vapor atomic fluorescence (Bloom 1989, USEPA 2001). There were two aqueous methyl mercury samples that were below the detection limit of $0.014 \mathrm{ng} / \mathrm{l}$.

\section{Data analysis}

Analysis of covariance (ANCOVA) (Sokal and Rohlf 1981) was used to assess differences in fish mercury levels among river locations, habitats, and time periods while controlling for the effects of fish size (i.e., total length). Location, habitat, and time period means were compared with a least squares mean (LSM) procedure that adjusted the individual means to the average fish length (Searle et al. 1980). Failure to collect fish from some habitats during some sample periods made it impossible to test all main effects and interactions in a single model that included all data. Instead, it was necessary to select portions of the data that permitted testing of the hypothesis of interest without incurring the problem of missing cells as discussed more fully later. Differences in aqueous mercury concentrations among locations, habitats, and time periods were analyzed with analysis of variance (ANOVA) (Sokal and Rohlf 1981). The two samples below detection limits were assumed equal to half the detection limit for analysis. Both fish tissue and aqueous mercury data were log transformed prior to analysis to meet statistical assumptions. Results were judged significant at $P \leq 0.05$. 
WSRC-MS-2002-01015

Mercury BAFs are typically calculated by dividing the average mercury concentration in fish by the average dissolved methyl mercury concentration (EPA 1997). This procedure yields a single value without an estimate of variability needed to compute confidence intervals. To avoid this problem, average BAFs plus $95 \%$ confidence intervals were calculated with a resampling procedure that involved randomly drawing (with replacement) a prescribed number of samples (indicated in results) from the potential pools of aqueous and fish tissue mercury samples appropriate for each combination of habitat, location, and time period under examination. Averages were calculated for the randomly drawn aqueous samples and the randomly drawn fish samples, and a BAF calculated by dividing the averages. This process was repeated 20,000 times and the $2.5^{\text {th }}$ and $97.5^{\text {th }}$ percentile were determined from the frequency distribution of the 20,000 BAFs. Coefficients of variation (CVs) were also computed from the frequency distribution by dividing the standard deviation of the BAF distribution by the distribution average. Computations were performed with Resampling Stats (Simon 1999) and Resampling Stats in Excel (Blank 1999).

\section{Results}

\section{Mercury in fish tissues}

A total of 225 fish were collected during the study: 60 during fall 2000 (24 largemouth bass, 28 sunfishes, and eight white catfish), 71 during spring 2001 (26 largemouth bass, 30 sunfishes, and 15 white catfish), and 94 during late summer 2001 (32 largemouth bass, 40 bream, and 22 white catfish). Average total lengths (standard deviation, range) were $18.7 \mathrm{~cm}(3.4,13-27)$ for sunfishes, $36 \mathrm{~cm}(5,25-47)$ for white catfish, and $31.2 \mathrm{~cm}(6.6,19-46)$ for largemouth bass. Fish tissue mercury concentrations (wet weight) ranged from nine to $1200 \mathrm{ug} / \mathrm{kg}$, but over $80 \%$ of the mercury concentrations were under $300 \mathrm{ug} / \mathrm{kg}$ (Figure 2). The arithmetic mean tissue mercury concentration for all species was $193 \mathrm{ug} / \mathrm{kg}$ with a CV (coefficient of variation = 
WSRC-MS-2002-01015

standard deviation/mean x 100) of approximately $99 \%$. However, the arithmetic mean was strongly influenced by a relatively small number of extremely high values. More representative measures of central tendency were the geometric mean and median, which were 130 and $128 \mathrm{ug} / \mathrm{kg}$, respectively. Geometric mean mercury concentrations for individual taxa were 209 ug/kg for largemouth bass, 147 ug/kg for white catfish, and $83 \mathrm{ug} / \mathrm{kg}$ for sunfishes. Qualitative examination of stomach contents indicated that largemouth bass primarily ate fish (Lepomis spp. and Dorosoma spp.), sunfishes ate aquatic insect larvae and other invertebrates, and white catfish ate aquatic insect larvae, molluscs (primarily Corbicula fluminea), other invertebrates, small numbers of fish, and detritus.

Because of an inability to consistently collect largemouth bass from the main channel, largemouth bass from both main channel and cuts were pooled for the ANCOVA of location and sample period on tissue mercury levels $(n=81)$. Largemouth bass total length was significantly related to tissue mercury concentrations $(P<0.001)$, and the relationship between fish length and mercury concentration was consistent across categories (i.e., slopes were homogeneous). Largemouth bass tissue mercury levels differed significantly among locations $(P<0.001)$ and among time periods $(P=0.011)$, but there were no significant interactions. Size adjusted concentrations were highest in the lower river and lowest in the upper river and somewhat higher during spring 2001 than during the other sampling periods (Figure 3 ). An additional ANCOVA using only fall 2000 and late summer 2001 data, when bass were collected from both main channel and cut habitats at all locations $(n=32)$, indicated that habitat related differences in tissue mercury levels were not significant (size adjusted geometric mean tissue levels were $213 \mathrm{ug} / \mathrm{kg}$ for the main channel and $200 \mathrm{ug} / \mathrm{kg}$ for the cuts). 
WSRC-MS-2002-01015

A preliminary ANCOVA with species as the categorical variable indicated a significant relationship between fish length and tissue mercury concentration but no significant differences among species for the three species pooled to produce the sunfish category, thus justifying the pooling of sunfish species for subsequent testing. As with largemouth bass, an inability to consistently collect sunfishes from the main channel made it necessary to pool fish from both main channel and cuts $(n=98)$ to test location and sample period. There was a significant relationship between total length and tissue mercury concentration $(p<0.001)$ and a significant difference among locations $(\mathrm{P}<0.001)$ but not sample periods. Size adjusted sunfish tissue mercury levels exhibited the same pattern observed with largemouth bass, highest in the lower river and lowest in the upper river (Figure 3).

Data from the late summer 2001 sample period, when sunfish were collected in substantial numbers from the main channel and cuts at all sample locations, were used to test for differences in sunfish tissue mercury levels between habitats $(n=40)$. This test indicated the occurrence of significant differences among both locations $(P<0.001)$ and habitats $(P=0.004)$ but no significant interaction. Size adjusted geometric mean sunfish tissue mercury levels were higher in the cuts $(117 \mathrm{ug} / \mathrm{kg})$ than in the river $(61 \mathrm{ug} / \mathrm{kg})$. Paralleling the previous tests, sunfish tissue mercury levels were highest in the lower river and lowest in the upper river.

Because preliminary analyses showed that tissue mercury levels in white catfish were not significantly related to fish length (possibly because the white catfish collected for analysis were comparatively uniform in size; i.e., total length $\mathrm{cv}=13.6 \%$ compared with $21.4 \%$ for largemouth bass and $18.4 \%$ for sunfishes), ANOVA rather than ANCOVA was used to test catfish for tissue mercury differences. Because white catfish were difficult to collect, the best test of sample period and habitat was with data collected from the middle river, where white catfish were consistently collected from both river and cuts 
WSRC-MS-2002-01015

during all sample periods $(n=28)$. This test indicated significant differences among sample periods (0.012) but not between habitats, nor were interactions significant. Geometric means were $281 \mathrm{ug} / \mathrm{kg}$ for fall 2000, $126 \mathrm{ug} / \mathrm{kg}$ for spring 2001 and $198 \mathrm{ug} / \mathrm{kg}$ for late summer 2001. Data from late summer 2001, when fish were collected from all locations, was used to test differences in catfish tissue mercury levels among locations $(n=22)$. As with largemouth bass and sunfishes, location related differences were significant $(\mathrm{P}<0.001)$, with the highest levels in the lower river $(372 \mathrm{ug} / \mathrm{kg})$, intermediate levels in the middle river $(198 \mathrm{ug} / \mathrm{kg})$ and the lowest levels in the upper river $(51 \mathrm{ug} / \mathrm{kg})$. Methyl mercury in water

Dissolved methyl mercury concentrations in water ranged from $<0.014$ to 0.470 ng/l with most concentrations under $0.1 \mathrm{ng} / \mathrm{l}$ (Figure 4). The arithmetic mean methyl mercury concentration was $0.081 \mathrm{ng} / \mathrm{l}$ with a CV of $113 \%$. However, as with the fish tissue data, this average was strongly influenced by a relatively small number of unusually high values making the median $(0.054 \mathrm{ng} / \mathrm{l})$ and geometric mean $(0.057 \mathrm{ng} / \mathrm{l})$ more representative measures of central tendency.

ANOVA of the log transformed methyl mercury data indicated a significant difference among sample periods but no other significant main effects or interactions. Geometric mean mercury concentrations were 0.048 during fall $2000,0.107$ during spring 2001, and 0.036 during late summer 2001 (Figure 5). Although dissolved aqueous methyl mercury levels during spring 2001 were relatively high in both the river and cuts, the highest levels were in some of the cuts.

\section{Bioaccumulation factors (BAFs)}

Differences in fish tissue and aqueous mercury concentrations associated with season and location affected BAF estimates as illustrated by computing average BAFs for different river locations during different sample periods. Water samples were pooled over location for this analysis because water concentrations did not differ significantly 
WSRC-MS-2002-01015

among locations. The average largemouth BAF ranged from $2.4 \times 10^{6}$ to $6.8 \times 10^{6}$ (Figure 5) representing a nearly three-fold difference depending upon when and where fish and water samples were collected. Sampling uncertainty was manifested in the $95 \%$ Cls for the largemouth bass BAFs which reached as low as $1.1 \times 10^{6}$ and as high as $11.9 \times 10^{6}$ ( $\mathrm{n}=10$ each for fish and water). Time period alone caused largemouth bass BAFs (averaged over location) to vary by a factor of approximately $1.9\left(2.9 \times 10^{6}\right.$ to $5.5 \times 10^{6}$ ), and location alone caused largemouth bass BAFs (averaged over time period) to vary by a factor of approximately $1.7\left(2.7 \times 10^{6}\right.$ to $\left.4.6 \times 10^{6}\right)$. Average sunfish BAFs ranged from $0.6 \times 10^{6}$ to $3.4 \times 10^{6}$, a nearly six-fold difference. Time period alone caused sunfish BAFs to vary by a factor of approximately $3.0\left(0.8 \times 10^{6}\right.$ to $\left.2.3 \times 10^{6}\right)$, and location alone caused sunfish BAFs to vary by a factor of approximately $2.3(0.8 \mathrm{x}$ $10^{6}$ to $1.9 \times 10^{6}$ ). Average white catfish BAFs ranged from $1.1 \times 10^{6}$ to $8.6 \times 10^{6}$, an approximately eight-fold difference. Overall average BAFs (including fish and water data from all periods, locations, and habitats) for each taxonomic group were $3.7 \times 10^{6}(95 \%$ $\mathrm{Cl}=2.4 \times 10^{6}$ to $\left.5.4 \times 10^{6}\right)$ for largemouth bass, $1.4 \times 10^{6}\left(95 \% \mathrm{Cl}=0.9 \times 10^{6}\right.$ to $2.1 \times$ $\left.10^{6}\right)$ for sunfishes, and $2.5 \times 10^{6}\left(95 \% \mathrm{Cl}=1.6 \times 10^{6}\right.$ to $\left.3.7 \times 10^{6}\right)$ for white catfish.

BAFs were also calculated by using geometric mean fish and geometric mean aqueous methyl mercury concentrations (since geometric means appeared to represent central tendency better than arithmetic means) and by using size adjusted geometric means (i.e., least squares geometric means) for fish tissue mercury in place of unadjusted geometric means (to control for differences in fish size among locations and time periods). Neither calculation substantially affected the differences among locations and time periods, although both reduced the confidence interval around individual means slightly. The lack of influence of the size adjusted geometric means indicated that $\mathrm{BAF}$ variability among locations and seasons was unrelated to fish size. 
WSRC-MS-2002-01015

It was necessary to increase both fish and aqueous mercury sample sizes to reduce the uncertainty associated with BAF estimates, as illustrated with an analysis based on the overall average largemouth bass BAF. Changes in fish and water sample sizes had similar effects on BAF variability. Very small sample sizes for either resulted in relatively high BAF CVs (Figure 7). The effect of sample size on BAF uncertainty was observed more explicitly by examining $95 \%$ confidence intervals for the overall average largemouth bass BAF (Figure 8). A sample size of five each for fish and water was associated with a confidence interval nearly $220 \%$ as large as the mean BAF. As sample sizes for both increased, the confidence interval (expressed as a percentage of the mean) decreased asymptotically, reaching approximately $78 \%$ of the mean at a sample size of 50 each for fish and water. In addition to causing considerable uncertainty, small $(<10)$ fish and water sample sizes resulted in slightly elevated average BAFs and highly skewed BAF distributions because of the strong influence of atypical data points on fish tissue and water concentration averages. This bias was minimal with larger samples which reduced the leverage of atypical data points.

\section{Discussion}

The Savannah River BAFs can be compared to the default BAFs recommended by the EPA (1997) for use when site specific data are lacking. For piscivorous fish, such as largemouth bass (trophic level four), the default BAF for dissolved methyl mercury in water and total mercury in fish is $6.8 \times 10^{6}$ (EPA 1997). This value exceeds the upper 95\% confidence limit for the overall average Savannah River largemouth bass BAF (3.7 $\times 10^{6}$ ), indicating it is not representative of mercury bioaccumulation in Savannah River largemouth bass. This is not surprising because BAFs vary substantially among water bodies (Southworth 1999). The difference between the EPA default BAF and the BAF for Savannah River largemouth bass indicates the importance of using site specific 
WSRC-MS-2002-01015

BAFs when possible. The EPA default BAF for invertebrate consuming fish (trophic level three, $1.6 \times 10^{6}$ ) agreed with the BAF for Savannah River sunfishes, which feed primarily on invertebrates $\left(1.4 \times 10^{6}\right)$. White catfish, which feed largely on invertebrates in the Savannah River but also consume some fish, had a BAF $\left(2.5 \times 10^{6}\right)$ intermediate between Savannah River largemouth bass and Savannah River sunfishes. Differences in BAFs among different types of fish were a direct consequence of taxa specific differences in fish tissue mercury levels that were probably associated with differences in trophic level, diet, and other factors (Kidd et al. 1995).

Of greater interest were variations in BAFs within individual taxonomic groups, which were larger than the differences between taxonomic groups. An important cause of this variation was spatial differences in fish tissue mercury levels. Mercury levels in all taxa, were highest in the lower river, intermediate in the middle river, and lowest in the upper river. Spatial differences in mercury levels have been reported in walleye Stizostedion vitreum from a Columbia River reservoir and attributed to local differences in the physical and chemical environment that affected mercury bioavailability (Munn and Short 1997). Proximity to anthropogenic sources of mercury pollution have also been linked to spatial differences in fish tissue mercury levels in a Virginia River (Hildebrand et al. 1976) and Florida estuaries (Strom and Graves 2001). However, there were no obvious point sources of mercury pollution in the Savannah River. There are numerous factors that can affect mercury bioaccumulation (Watras et al. 1998, Bowles et al. 2001), and additional research will be needed to explain the patterns observed in the Savannah River.

Although its influence was not as strong as location, season also had a significant effect on fish tissue mercury levels, with largemouth bass exhibiting higher levels in the spring and white catfish exhibiting lower levels in the spring. The pattern exhibited by largemouth bass was congruent with the pattern exhibited by aqueous 
WSRC-MS-2002-01015

methyl mercury, which was also significantly higher in the spring. The long biological half-life of methyl mercury in fish muscle (McKim et al. 1976, Burrows and Krenkel 1973) would be expected to limit seasonable variability in fish tissue mercury levels, and several field studies support this lack of seasonal change (Francis et al. 1998, Foster et al. 2000). However, at least one study indicates substantial seasonal variation in largemouth bass muscle tissue mercury levels attributable to changes in methyl mercury intake, which is potentially more variable (with changes in diet) than methyl mercury elimination (Park and Curtis 1997). Seasonal dietary shifts may have contributed to the temporal variability observed in fish tissue mercury levels in the Savannah River, although more intensive studies will be needed to verify this hypothesis.

Habitat (main channel versus cuts) also influenced mercury levels, although only in sunfishes. Higher levels in sunfishes from the cuts may have been related to the seasonal occurrence of relatively high aqueous methyl mercury levels in this habitat (Figure 4). Failure of largemouth bass and white catfish to also exhibit higher mercury levels in the cuts might be related to their greater mobility. Many stream dwelling sunfishes occupy relatively small home ranges in the order of 100 linear m (Berra and Gunning 1972, Gatz and Adams 1994), while largemouth bass occupy home ranges of approximately $1000 \mathrm{~m}$ in the Savannah River (unpublished data) and exhibit considerable movement between the main channel and tributary streams (Jones 2001). Movement patterns of white catfish are largely unknown, but channel catfish Ictalurus punctatus range up to $5 \mathrm{~km}$ in rivers and move between main river channels, tributary streams, and oxbow lakes (Dames and Coon 1989, Flotemersch et al. 1997). Largemouth bass and white catfish may integrate mercury exposure across habitats as a result of their relatively extensive movements.

Like mercury levels in Savannah River fish, methyl mercury levels in Savannah River water were highly variable and contributed to the high variability observed in the 
WSRC-MS-2002-01015

mercury BAFs. For logistical reasons, aqueous mercury sample replication was limited to two for each combination of location, habitat, and time. However, even this was sufficient to detect significant differences between time periods, with mercury concentrations averaging approximately two times higher during the spring than during the summer and fall. This difference was probably related to seasonal differences in the activity of mercury methylating bacteria associated with temperature, water quality or other factors. Aqueous methyl mercury concentrations have shown seasonality in other studies, peaking in July in the northern Florida Everglades (Hurley et al. 1996) and increasing in the fall in Wisconsin Lakes (Watras et al. 1995).

In summary, mercury levels in Savannah River fish depended on fish size; location; season; and, in the case of sunfishes, whether fish were collected from the river or the cuts. Aqueous methyl mercury levels depended on season. These sources of variation resulted in taxa specific mercury BAFs that varied by factors of three to eight (depending upon taxa) for the $118 \mathrm{~km}$ reach of the Savannah River under study. There was also considerable sampling uncertainty in both fish tissue and aqueous mercury concentrations likely resulting from analytical error, individual metabolic differences, and other unidentified factors. Because water quality targets calculated with the EPA's human health based methodology for mercury are inversely and linearly dependent upon BAFs (USEPA 1997), commensurate variation can be expected in water quality targets, in TMDLs derived from water quality targets, and in waste load allocations derived from TMDLs. The ultimate result could be unnecessary economic impact or insufficient protection of human health.

Savannah River data indicate the importance of sampling extensively in time and space for both fish tissue and aqueous mercury concentrations to produce accurate and representative BAFs in rivers. This includes sampling throughout the reach that the BAF will represent, sampling in different habitats that may vary in methyl mercury production, 
WSRC-MS-2002-01015

and sampling seasonally. Another necessity is to collect large numbers of fish and water samples to maximize precision and avoid potentially large BAF variations related to unexplained sampling variance. Approximately 50 fish tissue and aqueous mercury samples were needed to stabilize BAF variability in this study. Even with this sample size, the $95 \%$ confidence interval for the overall average largemouth bass BAF was $78 \%$ of the mean indicating the difficulty of obtaining precise BAF estimates.

\section{$\underline{\text { Conclusions }}$}

1) Fish tissue methyl mercury levels in the Savannah River exhibited significant variation related to location in the river, season, habitat, species, and fish size. Aqueous methyl mercury exhibited significant variation related to season.

2) BAFs for individual species of Savannah River fish varied by factors of three to eight depending upon when and where fish and water samples were collected.

Substantial sampling uncertainty suggested the possibility for even greater variation.

3) Determination of a representative and precise BAF necessitates collecting fish and water methyl mercury samples from the entire area to be represented, including different habitats within the area, and across seasonals. Large and approximately equal numbers of fish and water samples are needed to maximize precision.

\section{Acknowledgements}

Special thanks is extended to A.V. Guanlao for analysis of mercury levels in fish tissues. Appreciation is also extended to J.W. Littrell, A. Corley, W.M. Fulmer, and R.J. Roseberry, for assistance with sample collection. The information contained in this report was developed during U.S. Department of Energy Contract No. DE-AC0996SR18500.

\section{References}

Berra TM, Gunning GE (1972) Seasonal movement and home range of the longear sunfish, Lepomis megalotis (Rafinesque) in Louisiana. Am Midl Nat 88:368-374. 
Blank S, Seiter C, Bruce P (1999) Resampling stats Excel. Resampling Stats, Inc., Arlington, Va. 110 pp.

Bloom NS (1989) Determination of picogram levels of methylmercury by aqueous phase ethylation, followed by cryogenic gas chromatography with cold vapor atomic fluorescence. Can J Fish Aquat Sci 46:1131-1140.

Bloom NS (1992) On the chemical form of mercury in edible fish and marine invertebrate tissue. Can J Fish Aquat Sci 49:1010-1017.

Bloom NS (1995) Mercury as a case study of ultra-clean sample handling and storage in aquatic trace metal research. Environ Lab 3-4:20-25.

Bowles KC, Apte SC, Maher WA, Kawei M, Smith R (2001) Bioaccumulation and biomagnification of mercury in Lake Murray, Papua New Guinea. Can J Fish Aquat Sci 58:888-897.

Burrows WC, Krenkel PA (1973) Studies on uptake and loss of methylmercury-203 by bluegills (Lepomis macrochirus). Environ Sci Technol 7:1127-1130.

Cabana G, Tremblay A, Kalff J, Rasmussen JB (1994) Pelagic food chain structure in Ontario lakes: a determinant of mercury levels in lake trout (Salvelinus namaycush). Can J Fish Aquat Sci 51:381-389.

Clarkson TW (1990) Human health risks from methylmercury in fish. Environ Toxicol Chem 9:957-961.

Cope WG, Weiner JG, Rada RG (1990) Mercury accumulation in yellow perch in Wisconsin seepage lakes: relation to lake characteristics. Environ Toxicol Chem 9:931-940.

Dames HR, Coon TG (1989) Movements of channel and flathead catfish between the Missouri River and a tributary, Perche Creek. Tran Am Fish Soc 118(6):670-679. Downs, SG, Macleod CL, Lester JN (1998) Mercury in precipitation and its relation to bioaccumulation in fish: a literature review. Water, Air, Soil Pollut 108:149-187. 
Eisler, R (1987) Mercury hazards to fish, wildlife, and invertebrates: a synoptic review. U.S. Fish Wildl. Serv. Biol. Rep. 85(1.10).

EPA (United States Environmental Protection Agency) (1991) Methods for determination of metals in environmental samples, EPA-600/4-91-010. Environmental Systems Laboratory, US Environmental Protection Agency, Cincinatti, Ohio.

EPA (United States Environmental Protection Agency) (1994) Clean Water Act 303(D) TMDL program. EPA 841-K-94-004. Department of Commerce, National Technical Information Service. Springfield, VA.

EPA (United States Environmental Protection Agency) (1997) Mercury study report to congress, volume III: fate and transport of mercury in the environment. EPA452/R-97-005. Office of Air Quality Planning \& Standards and Office of Research and Development. December 1997.

EPA (United States Environmental Protection Agency) (2000) Total maximum daily load (TMDL) development for total mercury in the middle/lower Savannah River, GA. USEPA Region 4, Atlanta GA.

Flotemersch JE, Jackson DC, Jackson JR (1997) Channel catfish movements in relation to river channel floodplain connections. Proc Annu Conf Southeast Assoc Fish and Wildlife Agencies 51:106-112.

Foster EP, Drake DL, DiDomenico G (2000) Seasonal changes and tissue distribution of mercury in largemouth bass (Micropterus salmoides) from Dorena Reservoir, Oregon. Arch Environ Contam Toxicol 38:78-82.

Francis DR, Jude DJ, Barres JA. 1998. Mercury distribution in the biota of a Great Lakes estuary: Old Woman Creek, Ohio. J. Great Lakes Res. 24:595-607. Gatz AJ Jr., Adams SM (1994) Patterns of movement of centrarchids in two warmwater streams in eastern Tennessee. Ecol Freshwat Fish 3:35-48. 
WSRC-MS-2002-01015

Gilmour CC, Henry EA, Mitchell R. 1992. Sulfate stimulation of mercury methylation in freshwater sediments. Environ Sci Technol 26:2281-2287.

Hurley JP, Krabbenhoft DP, Cleckner LB, Olson ML, Aiken GR, Rawlik, PS Jr (1998) System controls on the aqueous distribution of mercury in the northern Florida Everglades. Biogeochemistry 40:293-310.

Jones TA (2001) Seasonal and diel movement of largemouth bass in a South Carolina stream. Unpublished thesis presented to the graduate school of Clemson University, Clemson, SC. 37 pp.

Kidd KA, Hesslein RH, Fudge RJP, Hallard KA (1995) The influence of trophic level as measured by deltaN15 on mercury concentrations in freshwater organisms. Water Air Soil Poll 80:1011-1015.

McKim JM, Olson GF, Holcombe GW, Hunt EP (1976) Long-term effects of methylmercuric chloride on three generations of brook trout (Salvelinus fontinalis): toxicity, accumulation, distribution, and elimination. J Fish Res Board Can 33:2726-2739.

Munn MD, Short TM (1997) Spatial heterogeneity of mercury bioaccumulation by walleye in Franklin D. Roosevelt Lake and the upper Columbia River, Washington. Tran Am Fish Soc 126:477-487.

Paller MH, Saul BM, Osteen DV. 1986. Distribution and abundance of ichthyoplankton in the mid-reaches of the Savannah River and selected tributaries. DPST-86798. Savannah River Site, Aiken, SC. 159 pp.

Park JG, Curtis LR. 1997. Mercury distribution in sediments and bioaccumulation by fish in two Oregon reservoirs: point-source and nonpoint-source impacted systems. Arch Environ Contam Toxicol 33:423-429. 
WSRC-MS-2002-01015

Regnell O, Ewald G, Lord E. 1997. Factors controlling temporal variation in methyl mercury levels in sediment and water in a seasonally stratified lake. Limnol Oceanogr 42:1784-1795.

Sokal RR, Rohlf FJ. 1981. Biometry, second edition. WH Freeman and Company, San Francisco.

Searle SR, Speed FM, Milliken GA. 1980. Populations marginal meansin the linear model: an alternative to least squares means. Am. Stat. 34: 216-221.

Sellers P, Kelly CA, Rudd JWM (2001) Fluxes of methylmercury to the water column of a drainage lake: the relative importance of internal and external sources. Limnol Oceanogr 46:623-631.

Simon JL (1999) Resampling stats user's guide. Resampling Stats, Inc., Arlington, Va. $122 \mathrm{pp}$.

Southworth GR (1999) Determination of site-specific aqueous concentration goals for controlling mercury bioaccumulation in fish in East Fork Poplar Creek: results of studies undertaken by the $\mathrm{Y}-12$ Biological Monitoring and Abatement Program (BMAP). Environmental Sciences Division, Oak Ridge National Laboratory, Oak Ridge, TN.

U.S. EPA. (Environmental Protection Agency) (2001) Guidance for Implementation and use of EPA Method 1631 for the determination of low-level mercury (40 CFR part 136). EPA 821-R-01-023. March 2001.

Watras CJ, Morrison KA, Host JS (1995) Concentration of mercury species in relationship to other site-specific factors in the surface waters of northern Wisconsin lakes. Limnol. Oceanogr. 40:556-565.

Watras CJ, Back RC, Halvorsen S, Hudson RJM, Morrison KA, Wente SP (1998) Bioaccumulation of mercury in pelagic freshwater food webs. Sci Total Environ 219:183-208. 
WSRC-MS-2002-01015

Figure Captions

1. Map showing Savannah River sample areas from which fish and water were collected for mercury analysis.

2. Total mercury concentrations in fishes collected from the Savannah River.

3. Size adjusted (least square) geometric mean total mercury concentrations $(95 \%$ confidence intervals) for largemouth bass and sunfishes collected from lower (L), middle (M) and upper (U) locations in the Savannah River during fall 2000 (1), spring 2001 (2), and late summer 2001 (3).

4. Dissolved methyl mercury concentrations in the Savannah River.

5. Geometric mean dissolved methyl mercury concentrations at different locations and during different seasons in the Savannah River.

6. Average mercury bioaccumulation factors (95\% confidence intervals) for the lower (L), middle (M) and upper (U) locations in the Savannah River during fall 2000 (1), spring 2001 (2), and late summer 2001 (3). Confidence intervals were calculated by resampling (see text for explanation).

7. Effects of number of fish samples and number of water samples on largemouth bass BAF coefficient of variation (CV). CVs were calculated by resampling (see text for explanation)

8. Relationship between sample size and the $95 \%$ confidence interval (expressed as a percentage of the mean) for largemouth bass bioaccumulation factors (BAFs). Sample size refers to number of fish samples and number of water samples (e.g., 10 indicates 10 fish samples and 10 water samples). Confidence intervals were calculated by resampling (see text for explanation). 
$W S R c-n s-2002-01015$






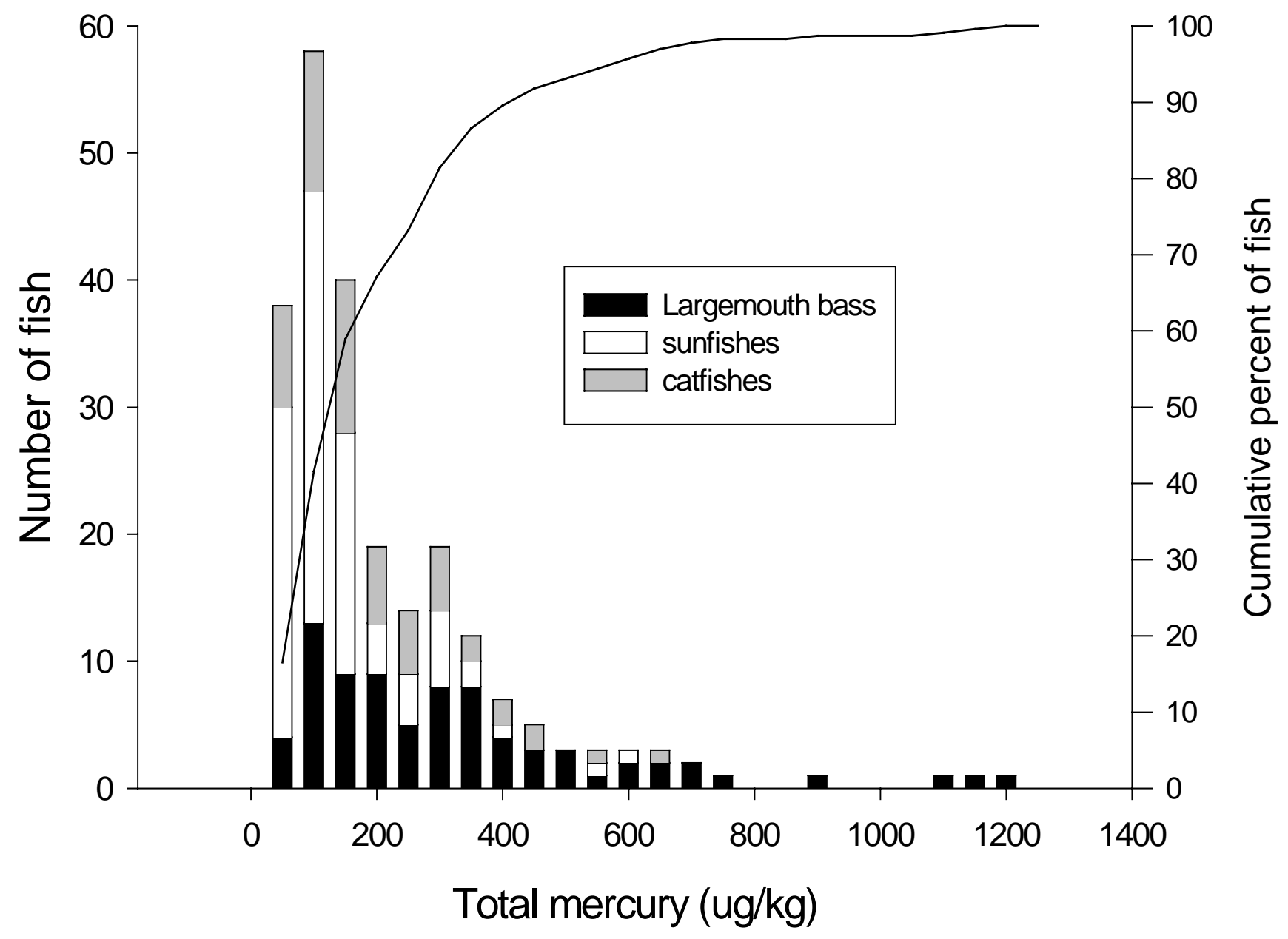



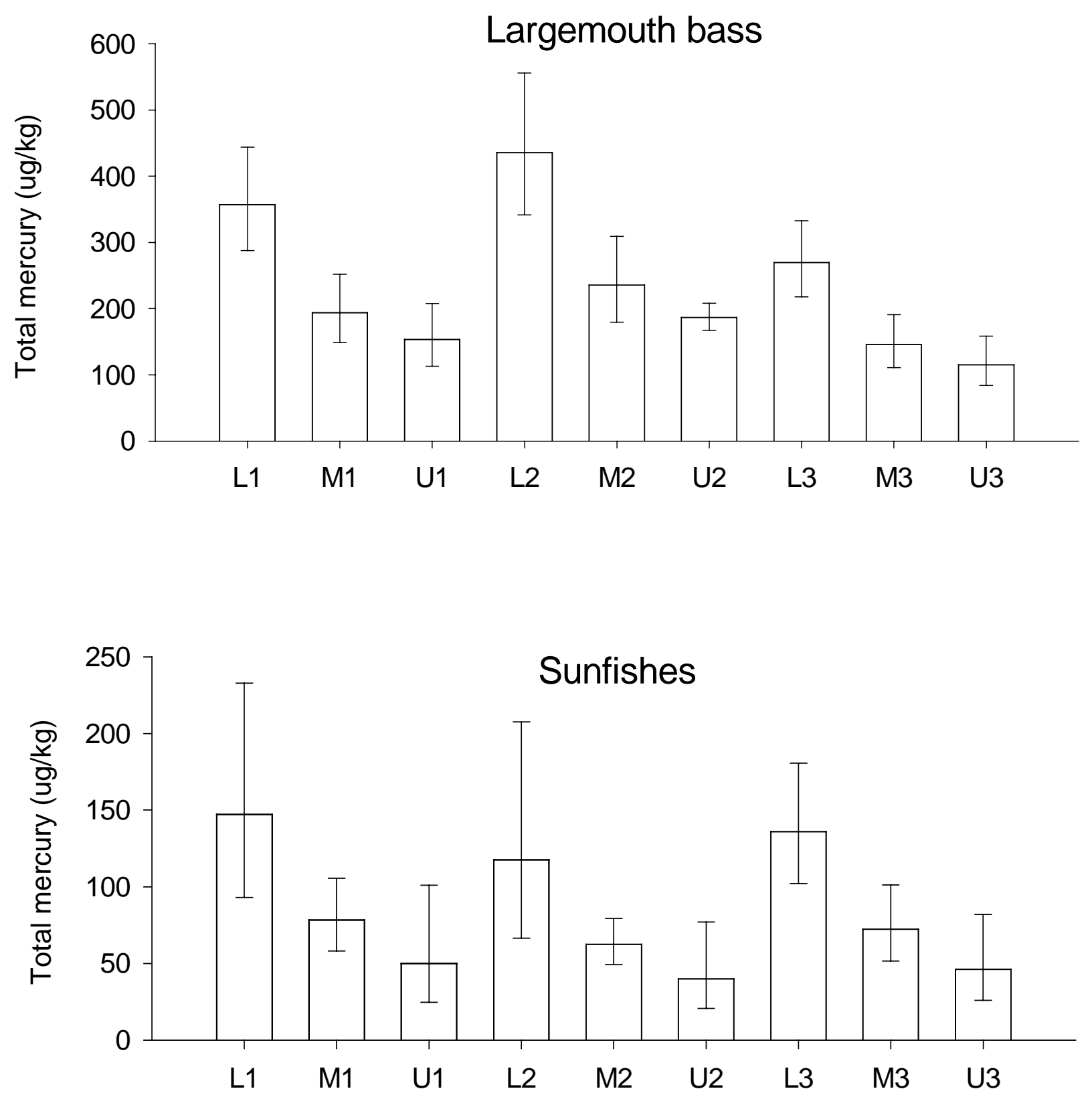


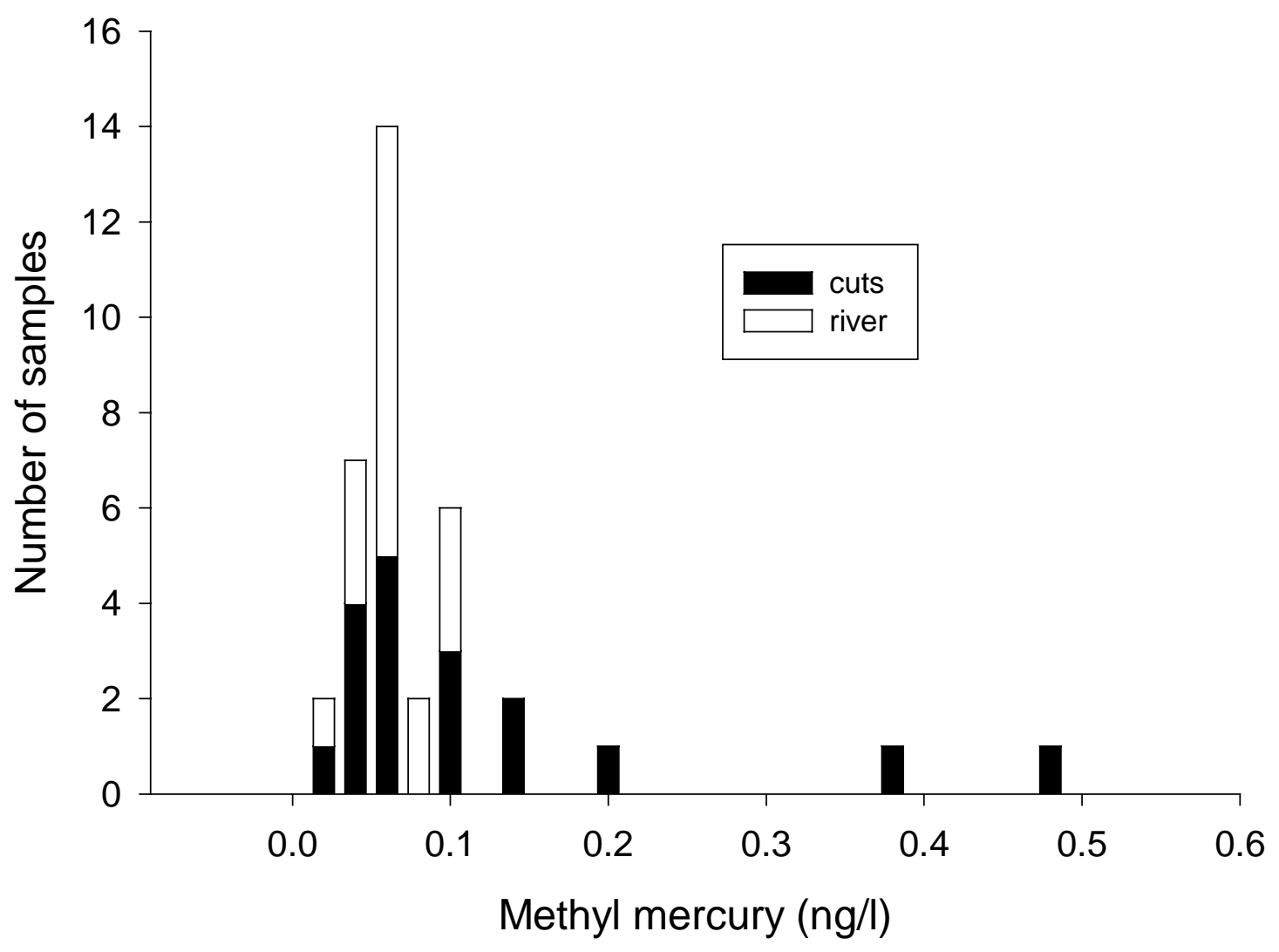




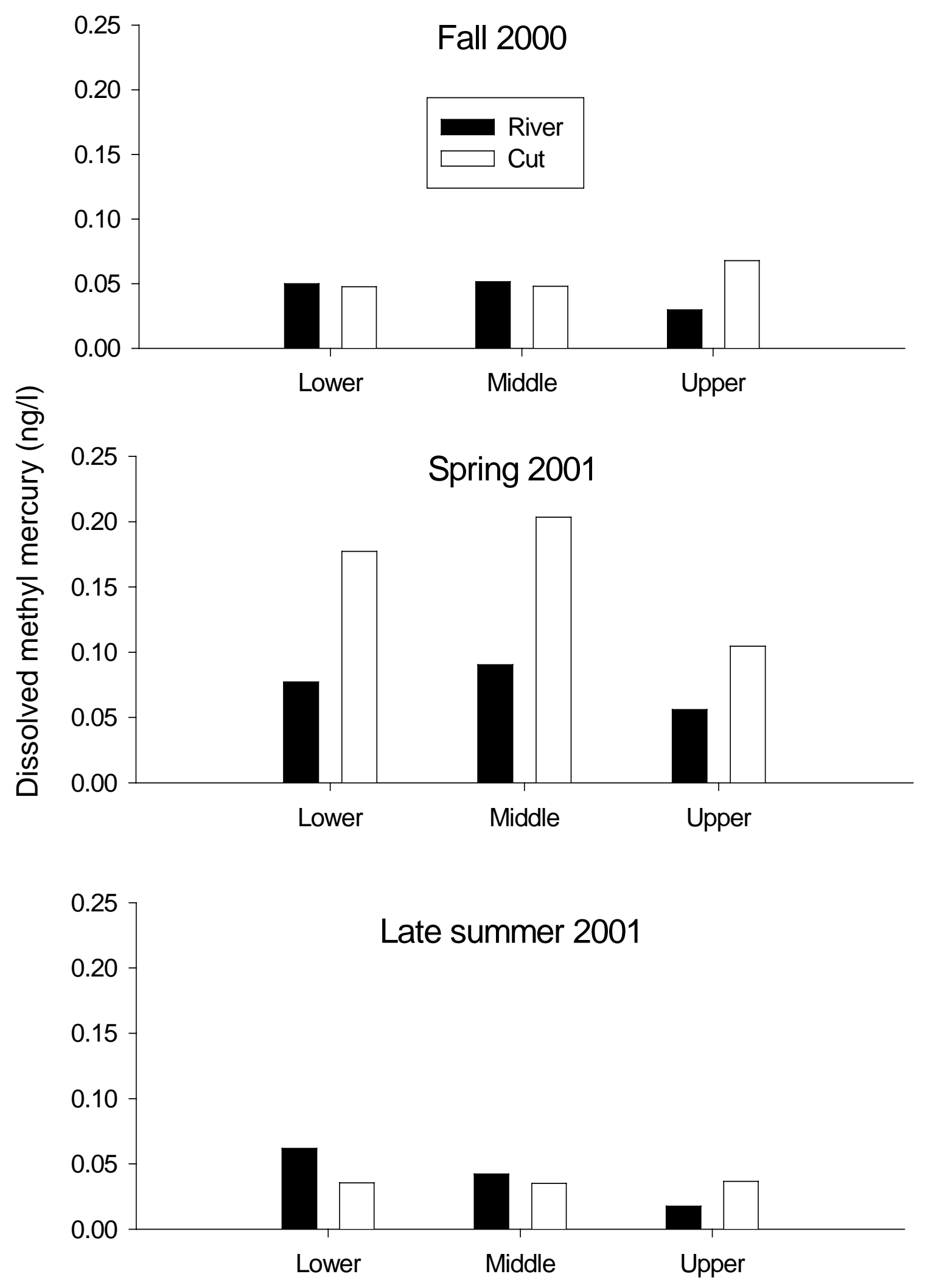



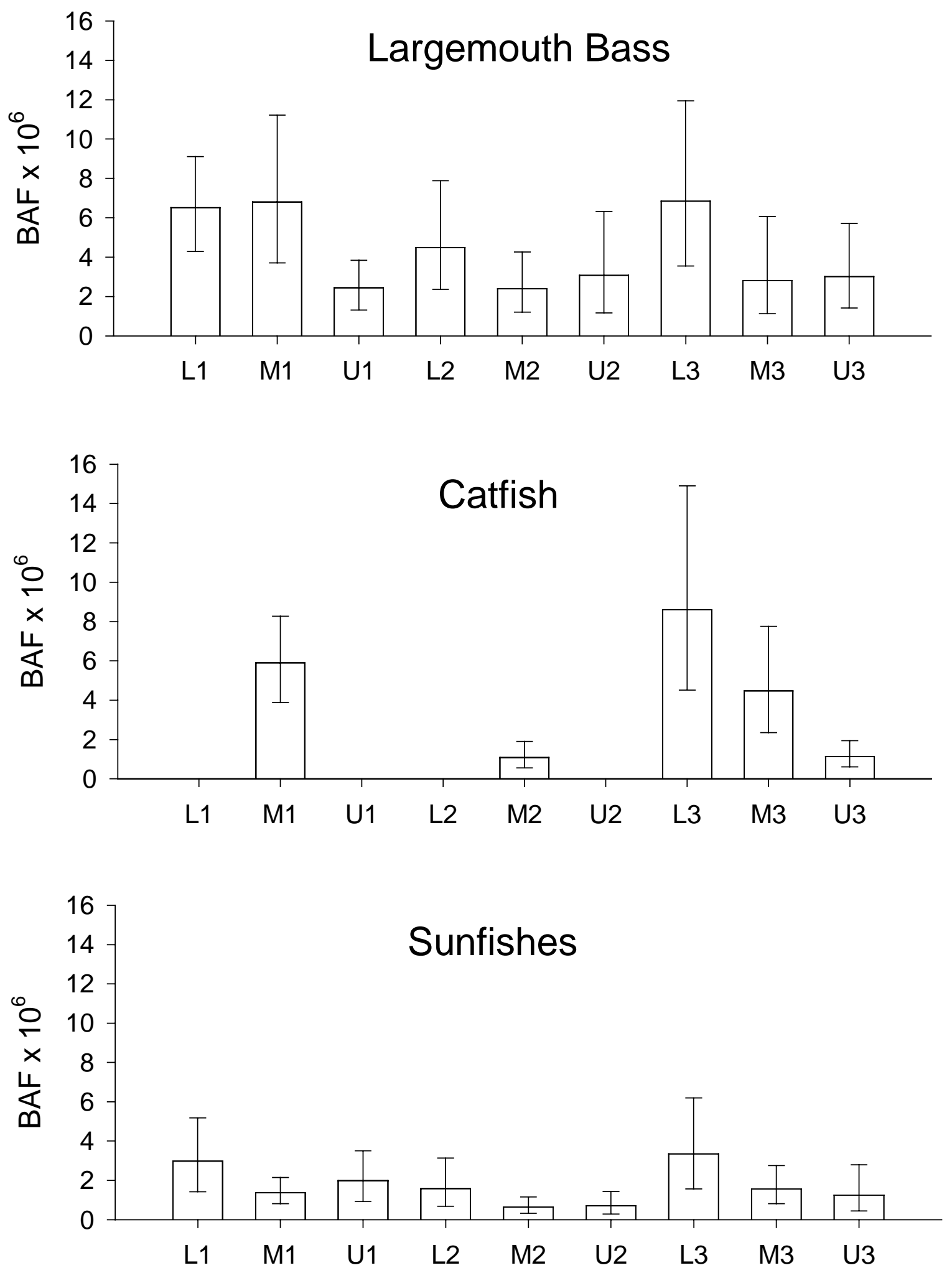
WSRC-MS-2002-01015

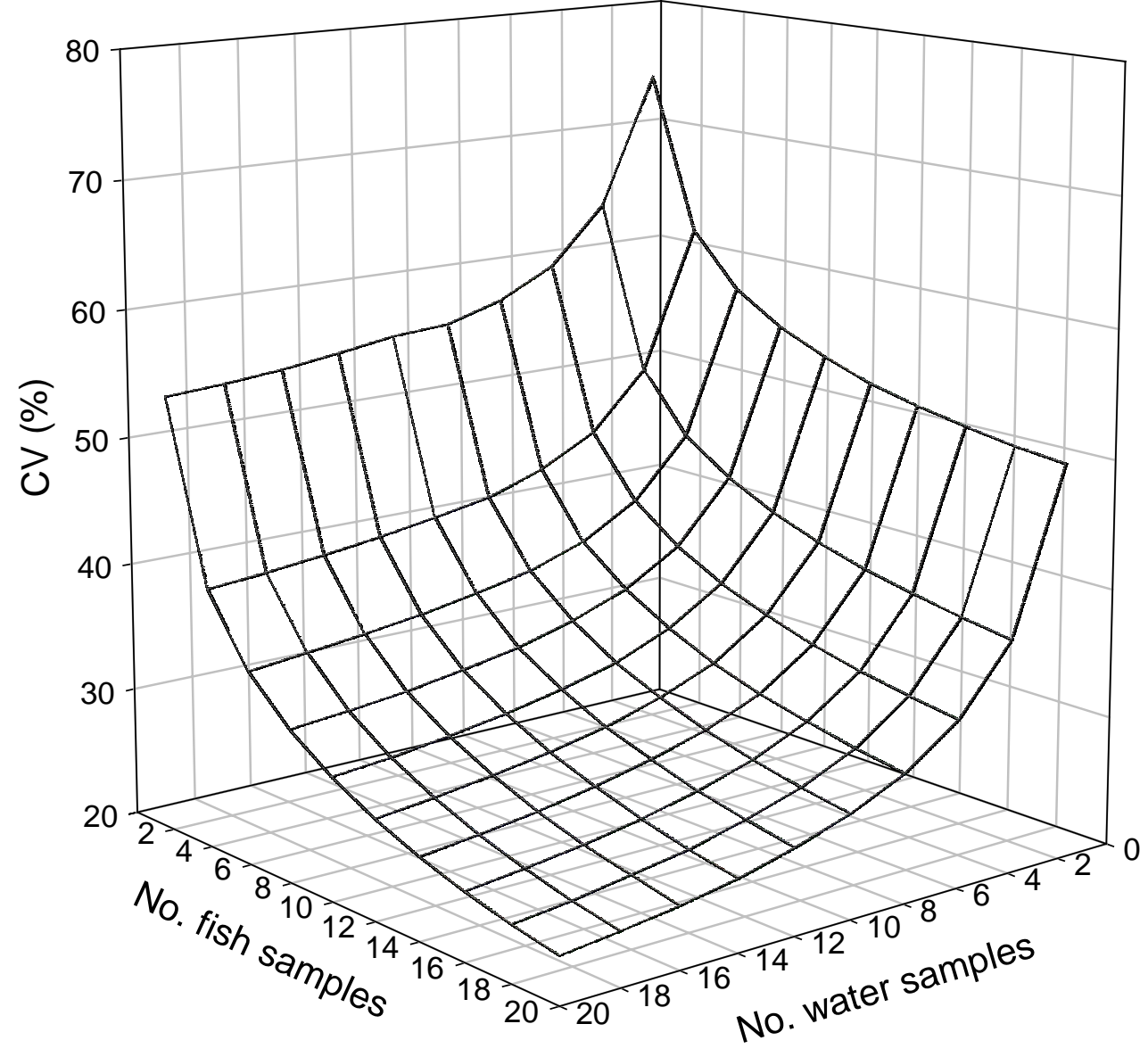


WSRC-MS-2002-01015

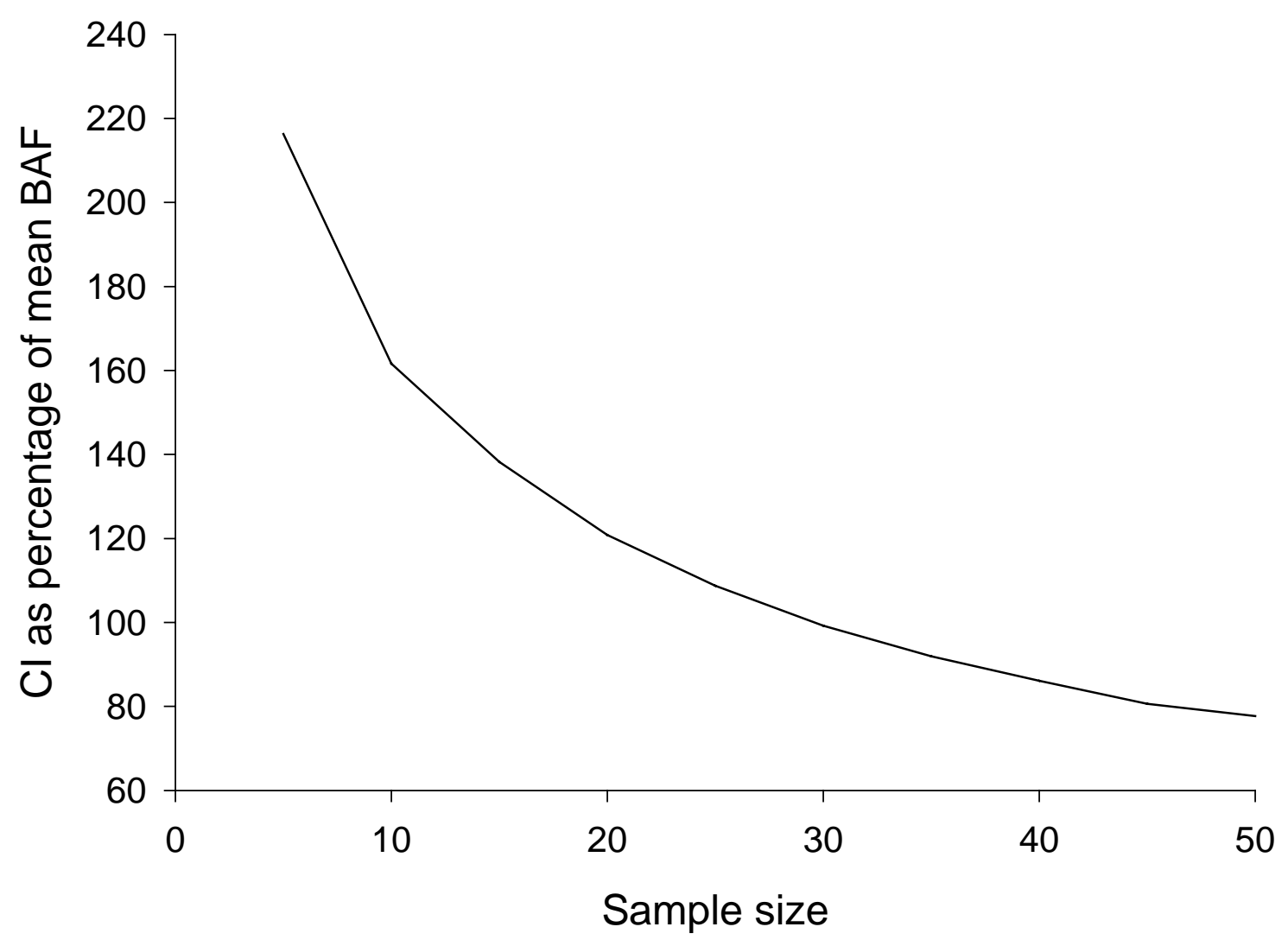

